\title{
VOLKSWAGEN EMISSIONS SCANDAL - A CASE STUDY REPORT
}

\section{PRASHANT SINGH}

Department of Organisational Behaviour and Human Resource Management, Indian Institute of Management (IIM) Udaipur, Rajasthan, India

\begin{abstract}
'Volkswagen (VW) Emission Scandal' considered as unitary of the highest profile scandal in the automotive industry and it will cause a profound impact not only on the German economic system but also in Europe. This scandal came to the news on $18^{\text {th }}$ September 2015. This scandal shows that how to achieve profit with a short span of time is disastrous and how the business happening in today's time will damage the environment. The purpose of this report is to dissect and identify the main organisational behaviour factors, which could be responsible for the adverse effect. It also provides an explanation of the problems, analyse the organisation's response and provide the robust recommendations, which could help future leaders learn and apply in future business.

KEYWORDS: Automotive Industry, Environment, Organisational Behaviour \& Leadership
\end{abstract}

Received: Aug 03, 2018; Accepted: Aug 24, 2018; Published: Sep 06, 2018; Paper Id.: IJHRMROCT20182

\section{INTRODUCTION}

\section{Organisation Background and Problems}

Volkswagen (VW) was founded in 1937 in Berlin and after ten years, post-World War II its headquarters shifted to Wolfsburg. Earlier VW used to manufacture military vehicles, but later started building passenger cars. In the mid-1950, VW expands its base to other geographic locations such as America, Asia, African markets (The Economist, 2016). This expands, lead to an increment in the popularity and then on August 1960 company modified its name and known as 'Volkswagenwerk Aktiengesellschaft', still the company is recognised by this epithet. In 2015, VW became the largest vehicle maker surpassing Toyota.

Soon after becoming the biggest automobile industry, on $18^{\text {th }}$ September 2015 , the significant emission scandal came into limelight publicly. The United States Environmental Protection Agency (EPA) announced that VW had violated the Clean Air Act (The Economist, 2016). According to the report, the EPA accused VW that the German automaker tried to pass the emission test by installing the 'defeat device'(Verschoor, 2016).

The report further outlined that the device can reduce the toxic fumes during the emission test. While driving the car at normal conditions, the device will be stopped, and the car generates $\mathrm{NO}_{\mathrm{x}}(\mathrm{Nitrogen}$ oxide) - a hazardous gas, which is highly injurious to health, which is 40 times higher than the personable limit(BBC, 2016). Furthermore, another report says that the Volkswagen violated the Kyoto Protocol on global warming. It's been estimated that the scandal might affect at least 11 million cars worldwide(The Guardian, 2015).

Earlier in 2014, the NGO has drawn attention on the toxic fumes emitted by VW cars and then the EPA required the producer to roll back the defective vehicles. Moreover, researchers from West Virginia University have also found that the cars are violating the norms of US standard(The Economist, 2015). 
California AirResources Board (CARB) had passed the report to EPA, and they have continued the test. Volkswagen initially denied the presence of any such device, but later some engineers have confessed that the vehicle contains the device. Later, VW publicly accepted the defect and massive recall of the defective cars happened (Financial Times, 2015).

As a consequence, a significant decline in VW's stock price and its revenue loss was \$ 1.84 billion. Some reports indicated that there would be the penalty of $\$ 18$ billion and would be difficult to establish confidence among the employees (The Guardian, 2015).

The crisis forced the CEO 'Martin Winterkorn' to resign and been supplanted by 'Porsche A. G. executive Matthias Mueller', who place the order of independent investigation(Volkswagen, 2015). Furthermore, few higher officials were suspended such as the head of brand development and Audi's and Porsche's R \& D head(Rescigno, 2015). VW in its official statement admitted that there is the necessity to establish the corporate culture where their employees could hold an open communication with their superiors (Tuttle, 2015).

\section{ANALYSIS OF ORGANISATIONAL BEHAVIOUR FACTORS}

About the media reports and the official statement, it clearly shows two main organisational behaviour problems, namely Leadership \& Corporate Social Responsibility (CSR) and Organisational Culture.

\section{Leadership \& Corporate Social Responsibility (CSR)}

The Volkswagen (VW) Emission Scandal does not blame the leader's capability or competencies but raises questions about the failure of character (Ba Banutu-Gomez \& Michael Ba, 2013).

Such flaws are the cause of the weak leadership, decision making, which later jeopardise the organisation (Carmeli, Gelbard, \& Reiter-Palmon, 2013). In that respect are three pillars which facilitate real leadership, they are Character, Competencies and Commitment (Efferin \& Hartono, 2015). If any of the trios would be lacking, it will contribute to the ruination of the system.

VW leaders are extremely educated and surrounded by bright colleagues, who possesses substantial expertise in their desired area. They could tackle any issue with ease, but the scandal proves that there is a want of inner drive - which is the principal dimension of a serious leader. Researchers brought out the 11 dimensions of leadership such as effort, collaboration, humanity, integrity, courage, accountability, justice, temperance, transcendence and judgement (Hoti, Hamdi, \& Edisona, 2016). For instance, high drive, but the absence of sobriety or integrity give rise to danger in the business. Hence, all the dimensions support the leaders to get a meaningful activity. Leadership is not about the directing the people, but it's about how to take a decision in a terrible situation, which makes sense and bring benefits to the organisation, employees, stakeholders, and the community(Jordan, Brown, Finkelstein, Brown, \& Trevino, 2013). The departed CEO, 'Martin' mentioned that the employees in the organisation are unable to express their concern freely. This strongly means that the leaders fail to utilise their full employee's potential and most of the work done in a dictatorial way(McCann \& Sweet, 2014).

From the media story, it has likewise been disclosed that the challenging decisions were hard. The inadequate flow of data from top to bottom was also one of the elements which contribute to this trouble (Mironescu \& Roxana, 2014). As VW is a large company so the decision-making procedure would also be cumbersome 
and most of the top leaders are overburden and stressed out, as a result, the important decision becomes hard to reach a conclusion.

One important aspect of leadership which lack in VW is the leader's critical and lateral thinking skills. It has been found that the more the leaders possess strong critical and lateral thinking skills, the ability to understand the complex issues enhances which helps to build a healthy relationship with their subordinates(Sun \& Anderson, 2012).

According to the official website Volkswagen has a strong corporate social responsibility (CSR) towards the environment and committed to ethics when it comes to the society. Nevertheless, establishing the 'defeat engine', defeat the intent of the system. In this current changing business environment, climate change is one of the important factors, and it has changed the dynamics of business(Bayoud \& Kavanagh, 2012). VW has the interest to make a profit within a short span of time and hence, the company overlooks the adverse effect on the environment. Without the 'defeat device,' the VW cars would emit 40 times higher nitrogen oxide - which is a clear violation of Kyoto Protocol.

The business industry should emphasise the importance to sustainable ways of answering business (Guliani, 2014). If the environment would be present, only than the human being would survive on this planet and simultaneously companies can do business, hence there is no point if any harm provided to the environment (Simmons, Shafer, \& Snell, 2013). Large corporations are often violating ethical rules, and everyone has to suffer. Many large companies comply with the ethical code of conduct and employees are bound to abide by it. To maintain the ethical standard, moral leadership is critical, and the company has to make sure that every executive follows it (Walker \& Dyck, 2014).

Many customers were interested in buying the VW car as the company portrait to provide the clean technology vehicles, which will not pollute the environment. The company was branding itself as an ecological pioneer in the automotive industry comes with a monetary value. Many years back similar thing has been acted by the Toyota corporation (Wilburn \& Wilburn, 2016). In lodge to take in a significant financial gain, the company has violated the environmental rules. Likewise, many companiesbreak the environment protocol and as a result, we as a human being pay the price (Linnenluecke \& Griffiths, 2010).

\section{Organisational Culture}

Volkswagen comes under the large corporations, and enormousorganisation consists of many levels inside it. Hierarchical levels of the organisationlead to bureaucratic culture, and the employees do not have full freedom (Hock, Clauss, \& Schulz, 2016). Mainly, employees work as a puppet under the direction of their supervisors and does not confront them.

In the public statement, the Volkswagen (VW) discloses that the management style is authoritarian, and the senior executive has set an ambitious goal, which has to be achieved at any cost. It clearly shows that the organisation has closed culture where the employees are not encouraged to have full freedom of speech and open dialogue (Linnenluecke \& Griffiths, 2010). Simultaneously, such circumstances limit search and balances and promote fraud and cheating. Mainly, the manufacturing industries, especially the automotive industry has the hierarchical structure and mechanistic structure which restricts the free thinking of employees (Škerlavaj, Štemberger, Škrinjar, \& Dimovski, 2007).

Volkswagen (VW) belongs in the same category and not the exception, and it has been found that the company which follow the hierarchal or dictatorial style of management style with their employees, chances are higher where the 
company will undergo such a difficult situation.

As the media report highlights that the enterprise CEO used the dictatorial style when it comes to deal with its talented engineer. This statement emphasises to have a more open form of communication, where the employee should get his/her freedom to express the opinion correctly, and the views would have importance in the growth of an organisation. Even the VW has a mechanistic structure, where each and every employee has a particular job role, but the management could have adopted the open and employee oriented culture. Due to lack of openness, the employee does not feel valued in the organisation as their views do not hold any importance in the decision-making process (Štok, Markič, Bertoncelj, \& Meško, 2010).

Companies which take the continuous learning and transparent culture approach usually enhance the creativity and productivity of their employees and they feel enthusiastic (Deem, DeLotell, \& Kelly, 2015). It motivates the employees to move forward and in the case of any discrepancy, employees are not afraid to raise it in front of the management. Variety in the talent pool should be present in the company which also facilitate the creativeness among employees (Brettel, Chomik, \& Flatten, 2015). Most of the senior officials at the VW were male German Engineers. As a result, the company was unable to have a different perspective and group decision making tends to have biases or certain prejudices.

Time involved resolving the complex matters raised the worry on the organisational culture too. The study proposed that if the management fashion is extremely bureaucratic and lethargical function, it causes a delay in the decision-making process and quite frequently the important step get delayed, and the whole arrangement has to hurt, which is what happens with Volkswagen (Vijayakumar \& Padma, 2014).

\section{VOLKSWAGEN'S RESPONSE}

Initially, EPA attempts to warn Volkswagen (VW) for its Diesel cars. Nevertheless, after the media coverage and scandal came out publicly, then company's CEO "Martin Winterkorn" took responsibility for the scandal and resigned from his position. Moreover, Winterkorn mentioned that he was unaware of any defeat device and engineers are to be charged for that. Head of the respective Department doesn't have any clue (Rescigno, 2015). Later, Martin apologised to customers and stakeholders for breaking the trust. The organisation then suspended $\mathrm{R} \& \mathrm{D}$ heads and ensured to regain the confidence back from the customers(The Guardian, 2015). The new CEO 'Mueller' assures that he would be executing secure protocol ever in the auto industry and will strain to regain confidence and trust through open communication and voraciousness (BBC, 2016).

Furthermore, Mueller has proposed the five-point strategy. Firstly, assist the customers who have suffered from the scandal. Secondly, investigate and identify the person responsible for the 'defeat device'. Third, will provide more autonomy to each region so that it will increase the efficiency and productivity. Fourth, Mueller will implement the openness in communication among the employees and would increase the cooperation. Lastly, will shift the 2018 strategy to 2025(Volkswagen, 2015).

\section{EFFECTIVENESS OF RESPONSE}

Whenever the scandal happens the organisationhead, people get suspended, and few higher officials put the resignation. The response received after the aftermath of the outrage is the obvious solution. Nothing special has been 
articulated from the organisation. However, the new CEO 'Mueller' five-point strategy is a good start, but its effectiveness has to be observed or its mere a tactic to reduce the toxicity inside the organisation. Till now, the organisation has not yet accepted that due to lack of effectiveness in the organisational culture, this scandal happened. Peter Henning, an expert in the automotive industry and white collar crimes states that the desire to betray comes from the highest level. According to him, when mid - level managers has to hit the specific target than people begin chiselling the edges. Hence, it's preposterous when higher level managers deny about the 'defeat device'. Thus, a technical fix can only be resolved through adaptive challenge - as this process is more in-depth change than others.

\section{CONCLUSIONS}

This scandal is the eye-opener which clearly shows the importance of ethical leadership and in this rapid changing business environment, how Corporate Social Responsibility (CSR) is an essential component of business. Large corporations should realise that they have an ethical duty towards the society as they are also part of it. Anything happens in the environment does not mean that the people who worked in such large corporations won't be affected. Sooner or later, they would also be affected.

Shifting forms of managing the business, push the firms to develop ground-breaking+ products to cater the needs, but taking a 'short cut' approach is not the answer. Unquestionably, shortly, the organisation might find success, but it's a failure in longer terms. Emphasis should be given to enhancing the existing skills and think to develop the innovative skills in a positive direction. Instead of utilising the talent to produce a 'defeat device', if VOLKSWAGEN uses the existing talent and investing more in the current talent to get the positive result than none of the organisation would be able to compete the VW. In the end, the highest level executive should put their ego and differences on one side and should work for the betterment of the organisation, as they have reached a level of which those higher officials should understand that they would be looked upon by their subordinates.

\section{RECOMMENDATIONS}

The new CEO of VW has proposed a few strategies, but based on the analysis of the Volkswagen Emission scandal case, these are my recommendations.

- The organisation should adopt the flat structure rather than hierarchical structure - in flat structure the information flow from top to bottom is smooth, and there would be less chance of distortion. It will help in utilising the leadership skills properly and give an opportunity to the employees to come up with innovative ideas.

- The decision - making should be decentralised - this will assist the upper-level executive to manage the unit properly, and people who have expertise in certain areas would receive the full authority to implement the right strategy for the betterment of an organisation. This will also boost up the employee confidence and help the employees to produce critical and lateral skills.

- The diversity of talent pool - sometimes when people from the same geographic location works together than efficiency gets reduced as existing people won't be able to receive fresh skills from outside. Diversity among each department would extend the purview of current accomplishments and admit a new itinerary for new expertise and talent to insert into the premise. 


\section{REFERENCES}

1. Ba Banutu-Gomez, M., \& Michael Ba, B.-G. (2013). The Pivotal Importance of Leadership, Knowledge Sharing and Organization Culture. The journal of American Academy of Business, Cambridge, 18(2), 238.

2. Bayoud, N. S., \& Kavanagh, M. (2012). THE IMPORTANCE AND BENEFITS OF CORPORATE SOCIAL RESPONSIBILITY DISCLOSURE IN THE LIBYAN CONTEXT: EVIDENCE FROM MANAGERS. Global Conference on Business \& Finance Proceedings, 7(1), 84.

3. BBC. (2016). VW plays sentimental card after emissions problems (pp. 12). London: Haymarket Media Group.

4. Brettel, M., Chomik, C., \& Flatten, T. C. (2015). How Organizational Culture Influences Innovativeness, Proactiveness, and Risk-Taking: Fostering Entrepreneurial Orientation in SMEs. Journal of Small Business Management, 53(4), 868-885.

5. Carmeli, A., Gelbard, R., \& Reiter-Palmon, R. (2013). Leadership, Creative Problem-Solving Capacity, and Creative Performance: The Importance of Knowledge Sharing. Human Resource Management, 52(1), 95-121.

6. Deem, J. W., DeLotell, P. J., \& Kelly, K. (2015). The Relationship of Employee Status to Organizational Culture and Organizational Effectiveness: A Quantitative Analysis. International Journal of Educational Management, 29(5), 563-581.

7. Efferin, S., \& Hartono, M. S. (2015). Management control and leadership styles in family business: An Indonesian case study. Journal of Accounting and Organizational Change, 11(1), 130-159.

8. Financial Times. (2015). The age of the whistleblower; Corporate crime. FT.com, 417(8967), 61.

9. Guliani, L. K. (2014). ORGANISATIONAL ETHICS: PARADIGM FOR CORPORATE SOCIAL RESPONSIBILITY. International Journal of Organizational Behaviour \& Management Perspectives, 3(3), 1116.

10. Hock, M., Clauss, T., \& Schulz, E. (2016). The impact of organizational culture on a firm's capability to innovate the business model. R\&D Management, 46(3), 433-450.

11. Hoti, H., Hamdi, H., \& Edisona, K. (2016). The role and importance of leadership in business development in Kosovo. Academic Journal of Business, Administration, Law and Social Sciences, 2(1), 99-104.

12. Jordan, J., Brown, M. E., Finkelstein, S., Brown, M. K., \& Trevino, L. K. (2013). Someone to Look Up To: Executive-Follower Ethical Reasoning and Perceptions of Ethical Leadership. Journal of Management, 39(3), 660-683.

13. Linnenluecke, M. K., \& Griffiths, A. (2010). Corporate sustainability and organizational culture. Journal of World Business, 45(4), 357-366.

14. McCann, J., \& Sweet, M. (2014). The Perceptions of Ethical and Sustainable Leadership. Journal of Business Ethics, 121(3), 373-383.

15. Mironescu, R., \& Roxana, M. (2014). THE IMPORTANCE OF MANAGEMENT AND LEADERSHIP IN A CHANGING BUSINESS ENVIRONMENT. Studies and Scientific Researches. Economics Edition (University of Bacau)(18).

16. Rescigno, R. (2015). Caution ahead: Volkswagen's troubles aren't over yet (Vol. 95, pp. 16). New York, N. Y: Dow Jones \& Company, Inc.

17. Simmons, R. S., Shafer, W. E., \& Snell, R. S. (2013). Effects of a Business Ethics Elective on Hong Kong Undergraduates' Attitudes Toward Corporate Ethics and Social Responsibility. Business \& Society, 52(4), 558-591.

18. Bhatla, n. Organizational citizenship behavior-literature review and theoretical framework. 
19. Škerlavaj, M., Štemberger, M. I., Škrinjar, R., \& Dimovski, V. (2007). Organizational learning culture—the missing link between business process change and organizational performance. International Journal of Production Economics, 106(2), 346-367.

20. Štok, Z. M., Markič, M., Bertoncelj, A., \& Meško, M. (2010). Elements of organizational culture leading to business excellence. Zbornik Radova Ekonomskog Fakultet au Rijeci, 28(2), 303-318.

21. Sun, P. Y. T., \& Anderson, M. H. (2012). The Importance of Attributional Complexity for Transformational Leadership Studies: Attributional Complexity and Leadership Studies. Journal of Management Studies, 49(6), 1001-1022.

22. The Economist. (2015). Dirty secrets; A scandal in the motor industry. The Economist, 416(8957), 15.

23. The Economist. (2016). Emission impossible; Volkswagen (Vol. 418, pp. 59). London: The Economist Intelligence Unit N. A., Incorporated.

24. The Guardian. (2015). Dieselgate: Audi boss in the eye of an emissions storm (pp. 44). London: Haymarket Media Group.

25. Tuttle, H. (2015). Volkswagen rocked by emissions fraud scandal (Vol. 62, pp. 4). New York: Risk Management Society Publishing, Inc.

26. Verschoor, C. C. (2016). THE VOLKSWAGEN PROBLEM (Vol. 97, pp. 15). Montvale: Institute of Management Accountants.

27. Vijayakumar, V. S. R., \& Padma, R. N. (2014). Impact of perceived organizational culture and learning on organizational identification. International Journal of Commerce and Management, 24(1), 40-62.

28. Volkswagen. (2015). Volkswagen CEO resigns amid emissions scandal (pp. 8).

29. Walker, K., \& Dyck, B. (2014). The Primary Importance of Corporate Social Responsibility and Ethicality in Corporate Reputation: An Empirical Study: Business and Society Review. Business and Society Review, 119(1), 147-174.

30. Wilburn, K., \& Wilburn, R. (2016). THE GROWING IMPORTANCE OF INTEGRATED REPORTING FOR CORPORATE SOCIAL RESPONSIBILITY. Global Conference on Business \& Finance Proceedings, 11(1), 379. 
